\title{
A könyvtárak az ELTE stratégiai céljai szolgálatában
}

\section{Tisztelt Főigazgató Asszony, kedves Kollégák!}

Megtisztelő számomra, hogy beszélhetek Önöknek arról, hogy az elkövetkező években milyen szerepet szán az egyetem vezetése az intézmény könyvtárainak tervezett fejlesztésére. Különösen érdekes számomra ebben a csodálatos teremben beszélni, ahol egyetemistaként oly sok időt eltöltöttem tanulással. Noha fizikai értelemben ma már sokkal kevesebbet járunk könyvtárba, mint annak idején, a könyvtár bővülö, átalakuló szolgáltatásai ma is nélkülözhetetlenek a tudósok és tanárok számára.

Ez év tavaszán készült el az egyetem 2016-2020 közötti periódusra vonatkozó Intézményfejlesztési Terve, az IFT. Több szempontból is különbözik ez a dokumentum a korábbiaktól: egyrészt a fenntartó világossá tette, hogy nemhogy fejlesztési pénzek, de még nagyobb pályázatok sem nyerhetők el, ha nincsenek összhangban az IFT-vel. Másrészt tavaly ősszel Rektor úr és Kancellár úr kezdeményezésére soklépcsős folyamat indult el annak érdekében, hogy kialakítsuk az egyetem hosszú távú vízióját, megfogalmazzuk értékeit, szerepét Magyarországon, a régióban és Európában. Ez a gondolkodás rányomta bélyegét a rövidebb távú tervezésre is. Véleményem szerint a korábbiaknál lényegesen használhatóbb dokumentum született.

Melyek is a leglényegesebb sarokkövek? Stratégiai cél, hogy az ELTE az európai mezőny meghatározó kutatóegyeteme legyen, vonzó környezetet biztosítva az oktatáshoz, kutatáshoz, valamint a hazai és a közép-európai régió egyik vezető egyetemi központjaként versenyképes diplomát nyújtson az itt végzett hallgatók számára. Azonban a hagyományokat megtartva továbbra is kiemelt feladatunknak tekintjük a nemzeti és az egyetemes kultúra és műveltség megőrzését és gyarapítását. Első olvasásra úgy tủnhet, hogy az IFT kifejtésébe kevés konkrétum került az Egyetemi Könyvtári Szolgálatról (EKSZ). Nézzük meg azonban egy kicsit jobban! Az IFT-ben lefektetett fő stratégiai irányok a következők:

- új, átfogó kiválósági program kidolgozása és elindítása a szakkollégiumok bázisán;

- a kiválóság erősítése a kutatás terén és a $\mathrm{K}+\mathrm{F}+\mathrm{I}$ lánc hiányzó elemeinek fejlesztése;

- a képzés hatékonyabb, fókuszáltabb nemzetköziesítése;

- az egyetem teljesítményének szisztematikus monitorozása, továbbá az oktatók teljesítményelvủ értékelésének megvalósítása. 
E négy cél melyike valósítható meg modernizált könyvtár nélkül? Egyik sem, hiszen a könyvtár szerepe mindegyikben megkerülhetetlen. A tehetséggondozás és a Kutatás - Fejlesztés - Innováció modern szakirodalom nélkül elképzelhetetlen. A hatékony oktatás új módszereket igényel, melyhez digitális eszközökben, tananyagokban a könyvtárosokra is számítunk. A nemzetköziesítéshez az idegen nyelvü könyvek és más információhordozók beszerzése szükséges, továbbá az egyetem teljesítményének monitorozása elképzelhetetlen adatbázisok nélkül, melynek legfontosabb ismeröi éppen a könyvtárosok. Éppen ezért az IFT megszületése után Könyvtári Stratégia született és kezdi meg göröngyös útját az egyetem döntéshozatali hierarchiájában. Ez a stratégia a Főigazgató asszony keze alatt az Önök segítségével készült. Az egyetem vezetése nevében köszönöm ezt a munkát. Melyek e stratégia legfontosabb pillérei, és hogyan szolgálják az egyetem céljainak megvalósulását?

\section{Legyen a könyvtár az ELTE tartalomszolgáltató tudásközpontja}

Az egyetem története, müködése során keletkezett, felhalmozott írott és tárgyi szellemi vagyont össze kell gyüjteni, archiválni kell és be kell mutatni a nagyközönségnek. Ennek érdekében ki kell alakítani a digitális egyetemi közgyüjteményt: e-tananyagok, e-tartalmak, az egyetem tárgyi és szellemi tudásvagyonának - mint például könyvtári, levéltári, muzeális dokumentumok, tárgyak, események, unikális gyüjtemények, publikációk, tudományos dolgozatok - digitalizálásával, felkutatásával, adatbázisban való feltárásával és közzétételével. A müködtetéshez ki kell dolgozni a szükséges szerzői jogi és közzétételi szabályozást is.

Tudásközpont: gyakran használt fogalom mostanában, de itt a helyén van. Tudást tárol, de egyben az itt dolgozók révén itt van e tudásvagyonnal való bánás tudománya is. Ezzel kell, hogy segítse a kutatást és az oktatást.

\section{Legyen a könyvtár az egyetem tudományos müködésének és tevékenysé- gének támogatója}

Sajnos, vagy nem sajnos, a teljesítményt minden szinten mérni kell, bármennyire legyen is absztrakt a produktum. Ebben is nagy szerepe van a könyvtárnak.

Az oktatói, kutatói teljesítményt mind bibliográfiai szinten, mind teljes szöveggel a lehető legmélyebb merítéssel be kell mutatni, mérhetővé kell tenni. Ezekkel támogatni kell a hazai és a nemzetközi kutatási együttmüködéseket, a tudományos és az intézményi minősítéseket, a minőségbiztosítást, az akkreditációt és a tudományos tevékenységeket, vagy éppen az IFT teljesülését. Ehhez meg kell erősíteni például az MTMT, az EDIT és a Stratégiai Adatbázis adminisztrátori hálózatát, és biztosítani kell a szükséges kompetenciákkal rendelkező emberi erőforrást. 
A kutató és oktató munkához be kell szerezni a szükséges adatbázisokat, támogatni és erősíteni kell az open access publikálást.

Mindezek erősítésére konzultációt és képzést kell szervezni az oktatók és az adminisztrátori hálózatban dolgozó munkatársak számára. Az oktatók képzése - ellenállásuk miatt - sok esetben nehéz dió lehet, mégis kérem, ebben is segítsenek minket türelemmel és megértéssel!

\section{Legyen a könyvtár tanulási központ és közösségi tér}

Már a bevezetésben említettem, milyen élmények füznek ehhez a teremhez. Meggyőződésem, hogy a könyvtár közösségi térként a digitális világban is megmaradhat, ha megtaláljuk a megfelelö funkciókat.

Olyan felhasználó-központú, felhasználóbarát szolgáltatásokat szükséges fejleszteni, amelyek az igényekhez jobban illeszkednek, a tanulást és a tanulás új formáit támogatják. A nyújtott szolgáltatásokhoz, az állományhoz és a dokumentumokhoz való teljesebb, gyorsabb, akadálymentes, korszerü felületeken és eszközökkel való hozzáférést kell biztosítani.

Ennek érdekében létre kell hozni a tanulást támogató fizikai és virtuális tereket, technikai és technológiai fejlesztésekkel a könyvtárt mint lehetséges közösségi teret be kell vezetni a használatba. A használói célcsoportok elégedettségét és igényeit folyamatosan mérni, elemezni és az eredményeket hasznosítani kell. Olyan „,egykapus” keresőfelületet, online idegen nyelvü szolgáltatási platformot kell 7/24 eléréssel biztosítani, amely az egyetemi partnerszervezetekkel közös fejlesztésekben születnek.

Egy apró példa az új funkciókra: Főigazgató Asszony segítségével itt tartottuk az egyetem Tudományos Napját, ahol többek között átadtuk az ELTE Ígéretes Kutatója elismerést. Azt hiszem, ennél méltóbb helye ennek a rendezvények nem lehet. Idén is ide tervezzük az ünnepséget.

\section{Legyen a könyvtár hatékonyan müködő szervezet}

Az ELTE sokszínủ egyetem. Ennek megfelelően könyvtárai is sokszínủek, nagyon különböző elvárásoknak kell megfelelniük. De a szolgáltatások színvonala egységes kell legyen, és a fejlesztéseket is célszerübb egységesen megvalósítani.

A felelösség, hatáskör és a feladatok újradefiniálása az EKSZ tagkönyvtárai (és az esetlegesen további bevonandó szervezeti egységek, közgyüjtemények) közötti belső munkamegosztást, az erőforrások jobb kihasználását, a szervezet hatékonyabb müködését kell, hogy eredményezze. Az Egyetemi Könyvtár által központilag nyújtott szolgáltatások és kibővített központosított feladatvégzés, a szolgáltatói attitüd erősítése eredményezi a kari és szervezeti egységek könyvtárainak hatékonyabb együttműködését, a helyi oktatási, kutatási igényeknek megfelelőbb szolgáltatások nyújtását. A kialakított központi szolgáltatások és a szakmai 
feladatok megosztása - például igény szerint központi beszerzés, feldolgozás, állományrevízió - lehetővé tennék az EKSZ tagkönyvtárak helyi szolgáltatásainak bővítését, minőségük emelését.

Az EKSZ mint több területen is együttmüködő szervezet rendelkezhet megfelelő humánpolitikai stratégiával, és alkalmas a magas kompetenciájú munkatársak bevonzására, megtartására. A humánstratégia központi elemeként fel kell mérni a hiányzó kompetenciákat, ki kell alakítani a szervezet és a munkatársak igényeihez igazított képzési tervet, be kell vezetni a teljesítményértékelést, a tudás és teljesítmény elismerésére irányuló rendszert, valamint ki kell alakítani az életpályamodellt. Mindezek következtében az EKSZ könyvtárainak és könyvtárosainak elismerése növekszik, amely megalapozhatja az átfogó stratégiai cél megvalósítását.

\section{Finanszírozás}

A célok egy része megvalósítható a meglévő anyagi erőforrások felülvizsgálatával, átcsoportosításával, a szervezet hatékonyságát növelő intézkedések megtételével, új feladatmegosztással, a belső erőforrások átcsoportosításával, az EKSZ erősségeinek kiaknázásával.

A stratégiai célokat, a szolgáltatások színvonalának emelését pályázati források bevonásával, az Egyetemi Könyvtárért Alapítvány támogatásával, a digitális közmunkaprogram lehetőségeinek kiaknázásával, a feladatok átszervezésével, és nem utolsó sorban a már korábban említett elkötelezett, lojális, megfelelően bérezett munkatársakra támaszkodva hatékonyabban lehet megvalósítani.

Az egyetem vezetésének azonban nincsenek illúziói: a jobbhoz ennél is több forrásra lesz szükség. Az információs, illetve tudástársadalomban az információ, a digitális tartalmak kezelése, az új szolgáltatások, a fejlesztések központi kezelést, irányítást, ennek következtében kiszámítható és elégséges büdzsét igényelnek.

A büdzsé kialakításának első sarkalatos pontja a teljes egyetem számára nyújtandó szolgáltatások, könyvtári/közgyüjteményi tevékenységek és müködés egyetemi infrastruktúraként való újradefiniálása. Ez maga után vonja, hogy a könyvtárakra, illetve az oktatást és kutatást támogató könyvtárakhoz kapcsolható egyes tevékenységekre fordítandó költségeket el kell különíteni. Ugyanígy a forrásokat: ebbe nem csupán az állami támogatást, de a kutatási pályázatok meghatározott részét is ide kell sorolni. A kutatási és oktatásfejlesztési pályázatok esetében is figyelembe kell venni a könyvtári információs szolgáltatásokhoz kapcsolódó IT fejlesztéseket, szoftver- és licencebeszerzéseket. A büdzsé tervezésekor kiemelt fontosságú többek között az idegen nyelvű szakirodalom, a folyóiratok, az adatbázisok beszerzése, valamint a publikációs tevékenység garantált és az igényeknek megfelelő támogatása, különös tekintettel az open accessre.

Az egyetem vezetése elkötelezett a könyvtári szolgáltatások fejlesztése mellett, hiszen tisztában vagyunk azzal, hogy a fejlesztési tervében leírt célok eléréséhez 
a könyvtárra, könyvárakra is szükség van. Lelkiismeretes munkájuk mellett már csak türelmet kell kérjek, hiszen az olyan változások, mint például a finanszírozás kapcsán említett átcsoportosítás, csak lassan valósíthatók meg. De már megtettük az első lépést: az EISZ önrészt központi forrásból fizette tavaly az egyetem, és idén is így készült a költségvetés.

A konferencia programjának alapján az elmondottak sok aspektusa kerül majd megvitatásra, tehát a rendezvény az ELTE könyvtári rendszere megújulásának is fontos lépése. Ezért aztán szívből kívánok Önöknek jó munkát és - tudományról és művészetről lévén szó - kellemes időtöltést.

SZALAY PÉTER

tudományos ügyek rektorhelyettese ELTE Eötvös Loránd Tudományegyetem ORCID: 0000-0003-1885-3557 